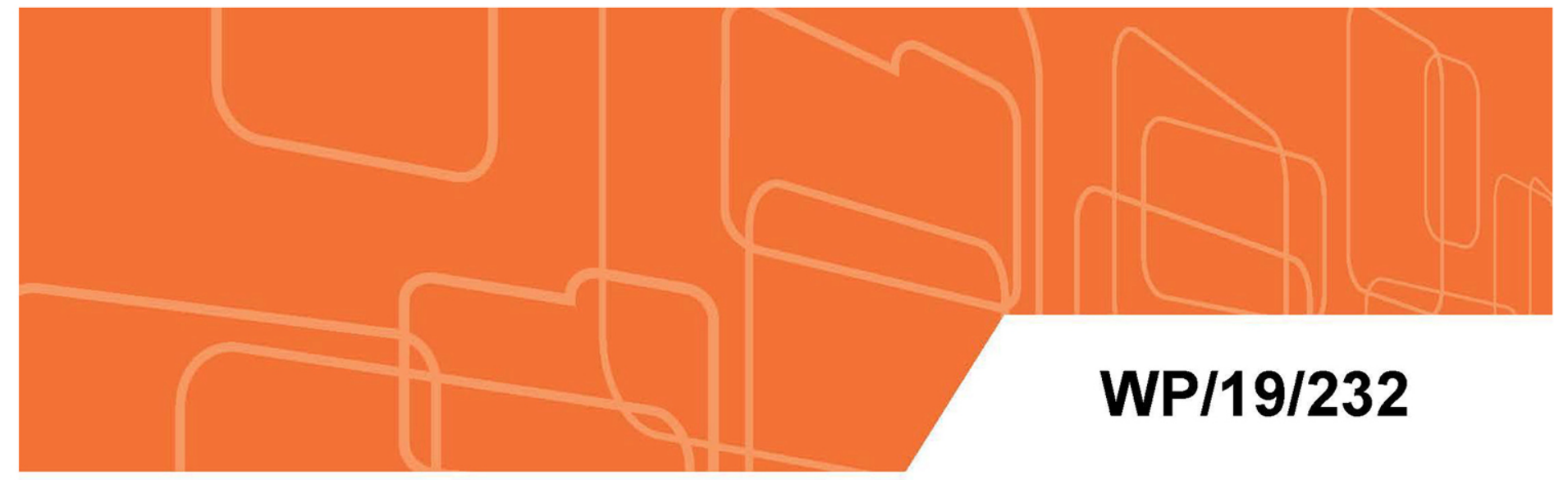

IMF Working Paper

\title{
On the Substitution of Private and Public Capital in Production
}

by Zidong An, Alvar Kangur, and Chris Papageorgiou

IMF Working Papers describe research in progress by the author(s) and are published to elicit comments and to encourage debate. The views expressed in IMF Working Papers are those of the author(s) and do not necessarily represent the views of the IMF, its Executive Board, or IMF management.

$$
\text { I N TER N A T I O N A L M O N E T A R Y F U N D }
$$




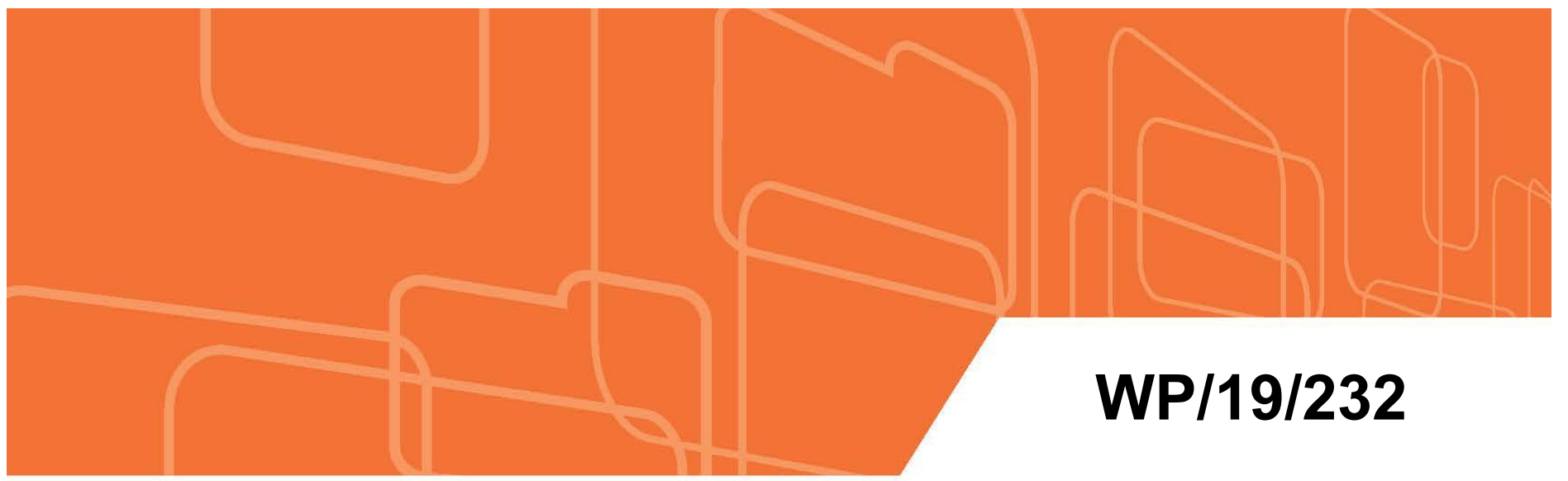

\section{IMF Working Paper}

\section{On the Substitution of Private and Public Capital in Production}

by Zidong An, Alvar Kangur, and Chris Papageorgiou

IMF Working Papers describe research in progress by the author(s) and are published to elicit comments and to encourage debate. The views expressed in IMF Working Papers are those of the author(s) and do not necessarily represent the views of the IMF, its Executive Board, or IMF management.

$$
\text { I N T E R N A T | O N A L M O N E T A R Y F U N D }
$$




\title{
IMF Working Paper
}

\author{
Research Department
}

\author{
On the Substitution of Private and Public Capital in Production ${ }^{1}$ \\ Prepared by Zidong An, Alvar Kangur, and Chris Papageorgiou \\ Authorized for distribution by Chris Papageorgiou
}

November 2019

\begin{abstract}
IMF Working Papers describe research in progress by the author(s) and are published to elicit comments and to encourage debate. The views expressed in IMF Working Papers are those of the author(s) and do not necessarily represent the views of the IMF, its Executive Board, or IMF management.
\end{abstract}

\begin{abstract}
Most macroeconomic models assume that aggregate output is generated by a specification for the production function with total physical capital as a key input. Implicitly this assumes that private and public capital stocks are perfect substitutes. In this paper we test this assumption by estimating a nested-CES production function whereas the two types of capital are considered separately along with labor as inputs. The estimation is based on our newly developed dataset on public and private capital stocks for 151 countries over a period of 1960-2014 consistent with Penn World Table version 9. We find evidence against perfect substitutability between public and private capital, especially for emerging and LIDCs, with the point estimate of the elasticity of substitution estimated closely around 3.
\end{abstract}

JEL Classification Numbers: O11, O16, O23.

Keywords: public capital, private capital, elasticity of substitution, production function.

Author's E-Mail Address: zan@imf.org, akangur@imf.org, cpapageorgiou@imf.org

\footnotetext{
${ }^{1}$ We are grateful to the editor and the three referees for valuable comments. We also thank Peter Pedroni, Felix Rioja and the seminar participants at the 11 th Southeastern International/Development Economics Workshop for helpful discussions. This work benefited from the financial support of the U.K. Department for International Development (DFID). The views expressed in this study are the sole responsibility of the authors and should not be attributed to the International Monetary Fund, its Executive Board, or its management. Data is available here.
} 


\section{Contents}

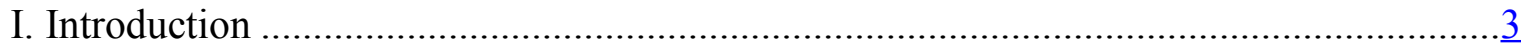

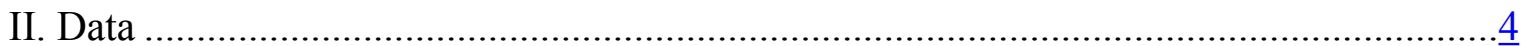

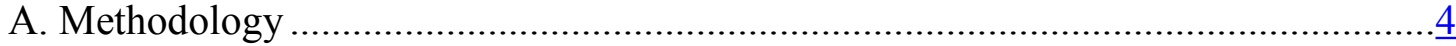

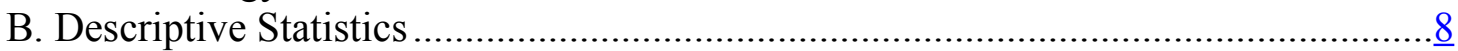

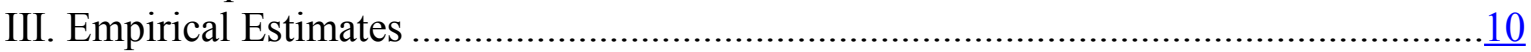

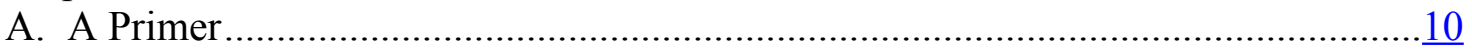

B. Elasticity of Substitution between Private and Public Capital................................11

IV. Sensitivity Analysis ..........................................................................................14

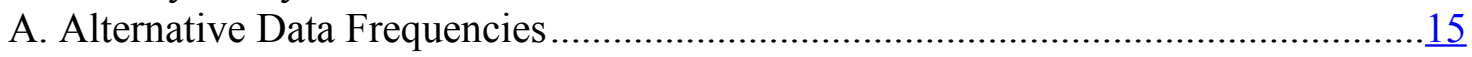

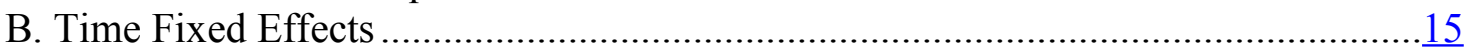

C. Controlling for Human Capital ......................................................................

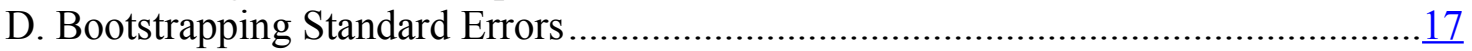

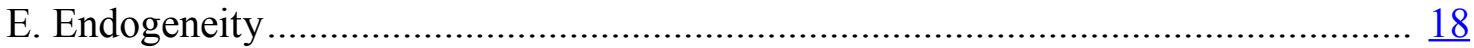

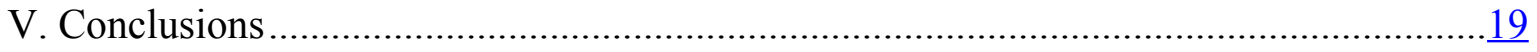

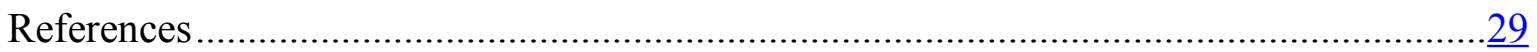

\section{List of Tables}

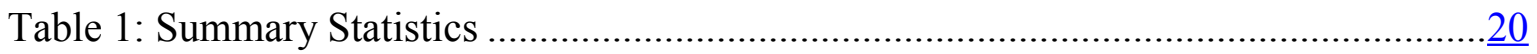

Table 2: Correlation of Growth Rates between Real GDP and Capital Stocks …………....20

Table 3: Two-level CES, Non-linear Least...................................................................21

Table 4: CES-nested-in-CD, Non-linear Least Squares ……………………………........

Table 5: Two-level CES, Alternative Data Frequencies...................................................22

Table 6: CES-nested-in-CD, Alternative Data Frequencies ................................................22

Table 7: CES-nested-in-CD, with Time Fixed Effects .................................................23

Table 8: Two-level CES, with Time Fixed Effects..........................................................23

Table 9: Two-level CES, Control for Human Capital, NLLS ..........................................24

Table 10: CES-nested-in-CD, Control for Human Capital, NLLS ......................................24

Table 11: Two-level CES, Bootstrapping ...............................................................25

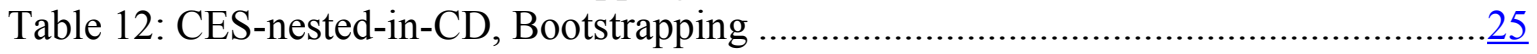

\section{List of Figures}

Figure 1: Investment Ratio and Growth Rate of Capital .................................................26

Figure 2: Elasticity of Substitution between Private and Public Capital, Bootstrapping of

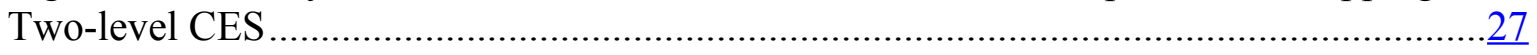

Figure 3: Elasticity of Substitution between Private and Public Capital, Bootstrapping of

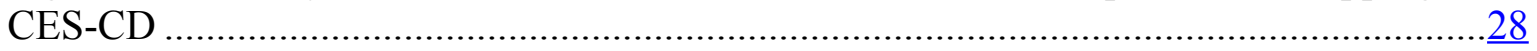

Figure A1: List of Countries by Income Group ……………………………………...... 


\section{INTRODUCTION}

After two generations of research papers focused on identifying the effect of public capital on economic activity, a broad consensus has been reached pointing to the favorable contributions of public capital to economic growth especially in early stages of economic development. Bom and Lighthart (2014) provide one way of summarizing these results by means of a meta-analysis using 578 estimates of output elasticities of public capital estimates. This analysis finds a long-run elasticity in the order of 12 percent, that increases to about 19 percent for core public capital and exhibits substantial heterogeneity across various dimensions, including income and regional differences. Allowing for cross-country heterogeneity, Calderón et al. (2015) find that the elasticity of output with respect to infrastructure capital ranges between 0.07 and 0.10 . Kangur and Papageorgiou (2017) document the evolution of the literature throughout the two generations of research papers. The first generation dates back to the seminal work of Aschauer (1989) which documents substantial growth effects of public capital and was later refined throughout the second generation of research on various methodological grounds as summarized extensively by Romp and de Haan (2007). ${ }^{2}$

Yet, macroeconomic models have largely assumed that public and private capital are perfectly substitutable in the aggregate production function or they are combined under the straitjacket of Cobb-Douglas aggregation function. Whether these prevalent assumptions are valid is an empirical question that this paper aims to answer by estimating the elasticity of substitution (ES) of the two types of capital.

This paper makes two contributions. First, we construct public and private investment and capital stock series for 151 countries covering 1960 - 2014. In doing so we ensure that at any point in time public and private investment and amortization levels are ex ante consistent with the aggregate economy-wide capital stock, investment, and amortization series reported in the Penn

\footnotetext{
${ }^{2}$ On the conceptual side, Turnovsky (2011) takes seriously the differentiated roles that public and private capital play along the transitional dynamics of a standard growth model. In a later contribution, Chatterjee and Turnovsky (2012) develop a model in which public capital is both an engine of growth and a determinant of the distributions of wealth, income, and welfare. Along the same lines, Agénor (2010) proposes a theory of long-run development based on public infrastructure as the main engine of growth. Also, in a recent book, Agénor (2012) discusses several potential channels through which public capital may contribute to long-run per-capita income growth. Apart from the traditional direct productivity-channel, which hinges upon the presence of gross complementarity between public infrastructure services and private inputs in goods production, Lowe et al. (2018) extend the Caselli and Feyrer (2007) cross-country estimation of the Marginal Product of Capital (MPK) by distinguishing between the public and private MPK.
} 
World Table (PWT) version 9. By treating these economy-wide series as observables and imposing the consistency requirements we are able to avoid making assumptions on historical or steadystate public and private investment growth rates typically required by existing approaches.

Second, with this new capital stock data at hand we examine whether public and private capital are complementary or substitutable in the aggregate production process. This is important as it challenges existing formulations of production functions that favor either a Cobb-Douglas aggregation between the two types of capital or, even more extreme, no disaggregation of the two types of capital thus implying that they are perfect substitutes. We show that for the entire sample of countries neither of the dominant assumptions in the literature are supported by the evidence which obtains a point estimate of the ES between public and private capital of around 3 . Furthermore, there exists substantial heterogeneity in these estimates across groups of countries the ES is shown to be higher for emerging countries than LIDCs while for advanced countries it is found to be well characterized by a Cobb-Douglas technology. These results hold well under various robustness tests including on alternative production structure, methodological approaches, and data sources.

The rest of the paper is organized as follows. Section 2 describes in detail data construction of public and private capital stocks. Section 3 sets the theoretical foundation of the empirical exercise and presents baseline empirical estimates of the ES between public and private capital. Section 4 reports results from an extensive robustness analysis. Section 5 concludes.

\section{DAtA}

\section{A. Methodology}

Construction of public capital stocks for a large set of countries that would be comparable acrosscountries as well as to the concepts of private or aggregate economy-wide capital stocks generally used in growth models is a notoriously hard task. While most empirical applications accumulate capital stocks with the perpetual inventory method, the practitioners have to overcome numerous obstacles due to lack of data on investment flows, measurement errors, estimates of (time-varying) depreciation rates, as well as methodological complexities in setting the initial conditions. 
Many studies avoid these challenges by using a variety of measures of physical infrastructure such as kilometers of paved roads or kilowatts of electricity-generating capacity that generally are more readily available. At the same time these are only partial measures of the aggregate public capital stock as they do not correct for quality, capture only some core aspects of public infrastructure, are not necessarily additive in terms of investment and amortization flows, and thus do not capture the overall general government activities. As such, mapping the estimates of public capital productivity or any deep parameters obtained from various measures of physical capital into production functions is not straightforward. Accumulating the public capital stocks with the perpetual inventory method can be problematic as well.

An inherent difficulty with accumulating economy-wide net capital stocks with the perpetual inventory method is determining the initial stock. Caselli (2005), Caselli and Feyrer (2007) as well as many others derive the initial conditions from a steady-state expression derived from a growth theory such as $I_{0} /(g+\delta)$ where $I_{0}$ is the value of the investment series in the first year, $g$ is the average geometric growth rate of the investment for a number of years after the initial year, and $\delta$ is the depreciation rate. The expression itself is that of a steady-state capital stock in the Solow growth model. While this is a well-acknowledged approach to derive the economy-wide capital series and can deliver reasonable estimates of the public capital stocks for advanced economies (see Dobbs et al., 2013) it can sometimes lead to implausible results when applied to generate public capital stocks for developing or low-income countries. This can be due to unavailability of public investment series over longer periods, or due to large variations in growth rates of public investment around the initial period, as well as the use of steady-state expressions that can be model-specific and potentially dependent on functional forms used that are themselves questionable.

To overcome the difficulties in setting the initial condition for the public sector capital stock Kamps (2006) applies an "asymptotic limit" approach by setting the capital stock in 1860 - a 100 years before the start of the empirical estimation period - to zero and using an artificial investment series over a period of 1860-1959 to get an initial capital stock estimate for 1960. The artificial investment series is constructed by applying an average investment growth over a period for which the data are available (1960-2001 in case of Kamps, 2006) backwards from the earliest year when the actual data are available. His sensitivity tests show that errors from the starting condition in 1860 and from assuming an artificial investment series diminish over time and do not have material 
effect on the dynamics of capital stock from 1960 onwards or on the econometric estimates of public capital elasticities.

The "asymptotic" approach has been applied successfully in several studies. Arslanalp et al. (2010) derive the capital stocks for 48 countries using public-private investment shares from the IMF World Economic Outlook (WEO) database, whereas Gupta et al. (2014) extend the coverage to 122 developing countries and introduce an efficiency-adjustment for 52 middle- and lowincome countries. The approach still has two distinctive features that can lead to measurement errors. First, the long-term average investment growth rate is not always the best proxy for the historical average, especially in countries undergoing structural changes. Second, when the aggregate capital stock is observed, it can be difficult to impose ex ante consistency between the levels of observable aggregate investment and amortization series with their private and public components.

In this paper we resort to an alternative approach that derives the unobserved public and private capital stocks from the observable economy-wide capital stocks and amortization levels, as well as respective investment shares of the components. The methodology used to construct the private and public capital stock series follows that in Collier et al. (2001), Kamps (2006), Arslanalp et al. (2010), Gupta et al. (2014), and International Monetary Fund (2015)3. That we make an extra effort here to make our capital stock series consistent with those in PWT9, is because PWT has been widely considered as the gold standard for empirical work, and also because of the PWT9's methodological advantages in their use of the perpetual inventory method (see Feenstra et al., 2015, Online Appendix, pp. 9-21).

An additional assumption that we need in our framework is that the price deflator used in the construction of the total capital is assumed to be the same for private and public capital. Consider the following system of equations where $K$ is the net capital stock, $I$ is the corresponding investment, $\delta$ is the average depreciation rate, $i$ and $t$ stand for country and year, and $P$ and $G$ denote private and public sectors, respectively:

$$
I_{i, t-1}=K_{i t}-\left(1-\delta_{i t}\right) * K_{i, t-1}
$$

\footnotetext{
${ }^{3}$ International Monetary Fund (2015) constructs a dataset that focuses on the investment efficiency using the public investment management index (PIMI) by Dabla-Norris et al. (2012).
} 


$$
\begin{aligned}
& I_{i, t-1}^{P}=s_{i, t-1}^{P} * I_{i, t-1}, \\
& I_{i, t-1}^{G}=s_{i, t-1}^{G} * I_{i, t-1} .
\end{aligned}
$$

The first equation defines the usual capital accumulation equation whereas the next two define public and private investment shares in total investment. If the total economy-wide capital stock can be observed, we can backward calculate aggregate investment from the difference equation and split it into private and public investment series. One concern related to the law of motion of capital is that investment accumulates into capital with delays. An advantage of our method is that the investment series are constructed based on the actual capital stocks. As a result, those are the investments that have already been accumulated into the capital stocks.

Next, we use the same difference equations to accumulate private and public capital stocks separately:

$$
\begin{aligned}
& K_{i t}^{P}=I_{i, t-1}^{P}+\left(1-\delta_{i t}^{P}\right) * K_{i, t-1}^{P}, \\
& K_{i t}^{G}=I_{i, t-1}^{G}+\left(1-\delta_{i t}^{G}\right) * K_{i, t-1}^{G} .
\end{aligned}
$$

While the method is straightforward, it requires time-series for an economy-wide capital stock, investment shares, and depreciation rates as well as estimates of the initial stocks of public and private capital. The data on economy-wide capital stock and average depreciation rates are retrieved from the Penn World Table (PWT) version 9.0 and are measured in 2011 US dollar. These time series start from as early as 1950 and vary by countries. The key series--the public and private investment shares--are calculated from the IMF World Economic Outlook (WEO) time series on private and general government gross fixed capital formation that for most countries start in 1969. Prior to 1969 the earliest available shares are extrapolated backwards to 1950 at which point we define the initial conditions for both public and private capital stocks by applying the investment shares to the economy-wide capital stock. ${ }^{4}$

While the economy-wide average depreciation rate is taken from the PWT, accumulation of public and private capital stocks requires splitting these into public and private depreciation rates.

\footnotetext{
${ }^{4}$ We have also calculated public and private capital stocks using WEO investment series denominated in local currencies. This investment dataset is highly correlated with our dataset and produces coefficient estimates that are close to the baseline estimates presented in Section 3. Both the alternative dataset and associated results are available upon request.
} 
We require the latter to satisfy two conditions. First, to maintain consistency, the depreciation of public and private capital (in PPP USD terms) must equal the total economy-wide capital depreciation. This is in line with Caselli and Wilson (2004) and Caselli and Feyrer (2007). Second, the depreciation rate of public capital is lower than that of private capital, in line with empirical evidence. ${ }^{5}$ We define the ratio of the depreciation rate of public capital to that of private capital as $r_{i, t}$ that we take from Gupta et al. (2014), which varies across time and across income groups. Under these conditions we can derive the depreciation rates for public and private capital as follows:

$$
\begin{aligned}
\delta_{i t}^{p} & =\frac{K_{i, t-1}}{K_{i, t-1}^{P}+r_{i t} K_{i, t-1}^{G}}, \\
\delta_{i t}^{G} & =\frac{r_{i t} K_{i, t-1}}{K_{i, t-1}^{P}+r_{i t} K_{i, t-1}^{G}},
\end{aligned}
$$

With this on hand, we have all the components to accumulate private and public capital stocks that are anchored in two consistency requirements that must be satisfied at all times: the sum of public and private investment must be equal to total investment (derived from observed total capital stocks). The data available from the PWT and the WEO allow us to construct public and private capital stocks for a panel of 151 countries covering the period 1950-2014. To alleviate any biases related to the choice of initial conditions we drop the first 10 years for estimation purposes. In 1960, the data consist of 102 countries. The number of countries with available data increases to 132 in 1970 and reaches 151 since 1990.

\section{B. Descriptive Statistics}

Table 1 provides some basic descriptive statistics of our data. The average investment to GDP ratio for all countries is around 26.5 percent though with large variation across country groups. On average, advanced countries invest much more in physical and in particular private capital; their total investment ratio exceeds that of LIDCs by about 10 percentage points of GDP. Similarly, the

\footnotetext{
${ }^{5}$ Hulten and Wykoff (1981) estimate the depreciation rates based on used asset prices. Fraumeni (1997) extends the range of assets and categorizes them into private and public assets. Gupta et al. (2014) apply different depreciation rates of private and public capital across income groups.
} 
differences in the composition of investment are rather striking: where public investment in advanced countries forms about one-fifth of total investment, in LIDCs the ratio increases to almost 40 percent. Such investment patterns translate into large differences in capital accumulation. In addition, while for emerging economies the public-private capital ratio is just over 50 percent, it is only 30 percent in advanced economies while exceeding an astonishing 75 percent in LIDCs. ${ }^{6}$ It is also worth noting that the standard deviation of the investment-to-GDP ratio, especially for the private investment, is much smaller for advanced economies compared to that for emerging economies and LIDCs. In economies that are in different stages of development, investment patterns are more heterogeneous. In addition, private investment accounts for a larger proportion of the cross-country heterogeneity in total investment, compared to public investment.

Table 2 summarizes the correlations between real GDP, and private and public capital, all in growth rates. In advanced countries public and private capital stocks are highly correlated. Also, their correlations with real GDP growth are high and similar in order of magnitude just above 0.5. This stands in sharp contrast to both emerging economies and LIDCs whose respective correlations are much lower. This is especially evident for public capital and output growth. When combined, these statistics point to a cautionary development tale: not only do lower income countries invest less, but their investment seems generally less productive and more driven by public investment that has the lowest correlation with growth. Due to lower public-private capital correlation the two capital stocks are more likely to be substitutes in emerging and lower income countries compared to advanced economies. Thus, based on the descriptive statistics there are good reasons to expect that the production technology in emerging and low-income countries is rather different from that in advanced economies.

Figure 1 depicts some of the time-series properties of the data. It is evident that previously reported differences in investment ratios mostly reflect the pre-2000 period. Over the past 15 years or so there has been strong convergence in the investment ratios among the three country groups. In advanced countries the public investment to GDP ratio has been on a secular decline since the 1980s, and more recently the global financial crisis has weighed heavily on private investment.

\footnotetext{
${ }^{6}$ In our data, public investment is measured as gross fixed capital formation in the public sector. This allows for the use of comparable data availability for a large number of countries. In contrast to the existing literature that focuses on infrastructure investment (e.g. Dobbs et al., 2013), our public investment and capital stock account for a relatively larger share of GDP.
} 
LIDCs, on another hand, have seen their private capital ratios increasing rapidly since the 1990s from very low levels in support of growth acceleration episodes. Consequently, both public and private capital growth rates in LIDCs have sharply accelerated while advanced countries have seen a decline in capital growth rates already since the 1970s. At the same time, there has been a remarkable divergence in public investment ratios. The public investment ratio has been on a secular decline in advanced economies, while it has rebounded strongly in emerging economies and LIDCs during the 2000s.

\section{EMPIRICAL ESTIMATES}

\section{A. A Primer}

Before turning to estimation results it is useful to clarify the underlying concepts and definitions. The general CES form of a three-factor production function that was pioneered by Arrow et al. (1961) is given by:

$$
Y=A\left(a L^{\rho}+b P^{\rho}+c G^{\rho}\right)^{1 / \rho},
$$

where $Y$ denotes output, $L$ denotes labor, and $P$ and $G$ denote the private and public capital, respectively. $A$ is the efficiency parameter, $a>0, b>0, c=1-a-b>0$ are the distribution parameters, and $\rho$ is the substitution parameter. The elasticity of substitution parameter between any two inputs is defined as:

$$
\sigma=1 /(1-\rho)
$$

Given the importance of this concept it is worth to recall the economics that lie behind these seemingly simple equations (8) and (9). The elasticity of substitution between any two factors is defined as a ratio of the percentage change in relative marginal products of the two inputs to a percentage change in the relative quantities of these factors. At the well-known extreme cases, $\rho=$ 1 implies an infinite elasticity of substitution (perfect substitutes) and a linear production function, whereas when $\rho$ approaches infinity the elasticity of substitution tends to zero, yielding the Leontief production function with inputs as perfect complements that can only be used in fixed ratios. 
In the Cobb-Douglas (CD) production function that given its wide use is often taken as a benchmark case, $\rho=0$, yielding a unitary elasticity of substitution. As the CD production function is consistent with the long-run stylized facts of Kaldor and often found to be empirically validated, economically interesting cases usually lie within its vicinity. However, a large body of literature has shown that the knife-edge CD production function in economic models is rejected.

In the CES function given by equation (8) the elasticity of substitution is the same for all three inputs. This does not have to be the case and given the nature of inputs is likely to be empirically invalid. To relax this assumption, we adopt a Sato (1967) two-level CES production function that allows for different, but still constant, elasticities of substitution between two inputs or nests of inputs:

$$
Y=A\left\{a\left[b P^{\theta}+(1-b) G^{\theta}\right]^{\rho / \theta}+(1-a) L^{\rho}\right\}^{1 / \rho}
$$

where $\theta$ is the substitution parameter between $P$ and $G$, and $\rho$ is the substitution parameter between the composite capital and labor $L$. This formulation encapsulates our key empirical test: what are the patterns of substitutability or complementarity between private and public capital?

\section{B. Elasticity of Substitution between Private and Public Capital}

We start our investigation by estimating the elasticity of substitution between private and public capital in a two-level CES specification with common time-trends: ${ }^{7}$

$$
Y_{i t}=A_{t} e^{\lambda t+\varepsilon_{i t}}\left\{a\left[b P_{i t}^{\theta}+(1-b) G_{i t}^{\theta}\right]^{\rho / \theta}+(1-a) L_{i t}^{\rho}\right\}^{1 / \rho}
$$

where $i$ denotes the country, $t$ denotes the time, and $\varepsilon$ is the error term. We assume exogenous and Hicks-neutral technical progress with $\lambda$ representing the technology growth rate and $A_{i}$ representing the initial technology level as well as any other time-invariant country fixed effects. The empirical specification (11) corresponds to the two-level CES production function (10). For the private $P$ and public $G$ capital stocks, we use our newly constructed panel data. Output $Y$ and

\footnotetext{
7 The CES aggregate production function estimation follows earlier work by Duffy and Papageorgiou (2000) and Duffy et al. (2006).
} 
labor input $L$ are measured as real GDP and total employment, both retrieved directly from PWT9. Capital stocks and output are measured in billions of 2011 US dollars and total employment is measured in millions of workers.

Though it is possible to linearize equation (11), the local approximation would have to impose strong restrictions on the functional form. For example, Kmenta (1967) himself notes that his approximation method may not perform well if the input share or the elasticity of substitution in the production function are either very high or very low. Thursby and Lovell (1978) and Koesler and Schymura (2015) also show that non-linear estimation performs significantly better than Kmenta approximations. Given the inherently non-linear nature of the CES production technology, our preferred estimation method is non-linear least squares (NLLS) which imposes less restrictions on the functional form with respect to the parameters of interest compared to linear least squares.

However, NLLS comes with the cost of some complexities in the estimation in a relatively large macro data set, which are further magnified when incorporating the country fixed effects $\left(A_{i}\right)$. Instead of estimating equation (11) directly, we first take the log-difference, in which the country fixed effects are differenced out:

$$
\ln \left(\frac{Y_{i t}}{Y_{i, t-1}}\right)=\lambda+\frac{1}{\rho} \ln \frac{a\left[b P_{i t}^{\theta}+(1-b) G_{i t}^{\theta}\right]^{\rho / \theta}+(1-a) L_{i t}^{\rho}}{a\left[b P_{i, t-1}^{\theta}+(1-b) G_{i, t-1}^{\theta}\right]^{\rho / \theta}+(1-a) L_{i, t-1}^{\rho}}+\left(\varepsilon_{i t}-\varepsilon_{i, t-1}\right)
$$

Table 3 reports the NLLS estimates of the two-level CES production function (12) on 3-year averages, splitting the results by country groups (full sample, advanced, emerging, and low-income developing countries). Coefficients and standard errors are estimated following the standard Levenberg-Marquardt nonlinear least squares algorithm. ${ }^{8}$ For the full sample of countries, the point estimate of the capital substitution parameter $(\theta)$ is 0.66 and statistically significant at the one percent level. This implies a public-private capital elasticity of substitution (ES) of 2.9. ${ }^{9}$ Therefore, our results strongly suggest that public and private capital are to a high degree substitutable, rejecting the Cobb-Douglas aggregation. The point estimate of the distribution parameter between public and private capital $(b)$ is 0.56 and statistically highly significant. At the same time the

\footnotetext{
${ }^{8}$ The Levenberg-Marquardt method is a popular technique to solve nonlinear least square problems. It is a combination of two minimization algorithms: the Gauss-Newton method and the gradient descent method.

9 The public-private capital elasticity of substitution (ES) is calculated as $1 /(1-\theta)$. One standard deviation confidence intervals in brackets are derived using the delta method.
} 
substitution parameter between the CES composite capital and labor $(\rho)$ is not statistically different from zero, implying that the Cobb-Douglas nesting with a unitary capital-labor elasticity of substitution cannot be rejected. The distribution parameter between the composite capital and labor (a) is estimated to be 0.61 and it is highly significant.

The estimated distribution parameter (a) reported obtains values seemingly larger than in the existing literature though they could reflect recent labor income shares trending down, especially over the last two of decades - a result which while being heterogeneous across countries finds strong support in several advanced economies and even more so in a much broader country sample (e.g. Gomme and Rupert, 2004, 2007; Karabarbounis and Neiman, 2013; International Monetary Fund, 2017, Chapter 3). Earlier work by Gomme and Rupert (2004) uses U.S. data and explores the BLS calculations with an eye to understanding the factors leading to the recent fall in labor's share but still at the high level of 0.71 in 2000. In a separate paper Gomme and Rupert (2007) calculate U.S. capital's share of income, as measured using private measures of income (share of market structures plus share of equipment and software), to be 0.283 . More recent estimates by Karabarbounis and Neiman (2013) report that US labor income share fell below 0.6 by 2010 . International Monetary Fund (2017, Chapter 3, Figure 3.1) reports labor share estimates for advanced economies during 1990-2014 to average slightly over 50 percent and for developing economies around 36 percent.

Splitting the results by country groups suggests that the high public-private capital substitutability is driven by emerging economies that form close to half of the overall sample. In this group the implied elasticity of substitution is estimated at 3.44. It is also worth noting that the elasticity of substitution between the composite capital and labor $(1 /(1-\rho))$ is estimated around 0.8 in line with Chirinko (2008). At the same time, growth rates in advanced countries are strongly driven by a common technology trend. Only the distribution parameters are significant whereas neither of the two substitution parameters are statistically different from zero. Thus, for advanced countries the production process can indeed be well characterized by a Cobb-Douglas technology. It is interesting to note that the overall fit is the best for advanced countries. Finally, the LIDCs are broadly between the advanced and emerging countries with a public-private capital elasticity of substitution estimated at 2.1 . 
Given that for the full sample the substitution parameter $\rho$ between the composite capital and labor is not statistically different from zero, following Stokey (1996) we next estimate the CES nested in Cobb-Douglas production function of the form:

$$
Y_{i t}=\left(A_{t} e^{\lambda t+\varepsilon_{i t}}\right) L_{i t}^{1-a}\left[b P_{i t}^{\theta}+(1-b) G_{i t}^{\theta}\right]^{a / \theta} .
$$

As before, we difference out the country fixed effects by taking the log-difference:

$$
\ln \left(\frac{Y_{i t}}{Y_{i, t-1}}\right)=\lambda+(1-a) \ln \left(\frac{L_{i t}}{L_{i, t-1}}\right)+\frac{a}{\theta} \ln \left[\frac{b P_{i t}^{\theta}+(1-b) G_{i t}^{\theta}}{b P_{i, t-1}^{\theta}+(1-b) G_{i, t-1}^{\theta}}\right]+\left(\varepsilon_{i t}-\varepsilon_{i, t-1}\right)
$$

Table 4 reports the NLLS estimates of the CES-nested-in-Cobb-Douglas production function (14). Compared with the results reported in Table 3, the estimated elasticity of substitution between public and private capital remains robust: the results for the full sample and emerging economies are almost identical to the baseline results. The distribution parameters are still precisely estimated Setting the substitution parameter $\rho$ equal to zero has little effect on the distribution parameter between private and public capital, while the distribution parameter between the CES composite capital and labor decreases. ${ }^{10}$

To sum up, we estimate the elasticity of substitution between private and public capital using our newly constructed panel data. We find that private and public capital are highly but not perfectly substitutable, with the point estimate of the elasticity of substitution around 3 . This finding is important because most macroeconomic models assume that aggregate output is generated by a production function specification with total physical capital as a key input. Implicitly this assumes that private and public capital stocks are perfect substitutes. However, since they are highly but not perfectly substitutable, neither a Leontief nor a Cobb-Douglas type aggregation should be applied to the private and public capital stocks in a production function.

\footnotetext{
${ }^{10}$ Worth noting that the baseline results in Table 3 and 4 are robust to using the efficiency-adjusted capital stock data in International Monetary Fund (2015).
} 


\section{Sensitivity Analysis}

In this section we conduct several robustness checks. First, we examine whether our baseline results are sensitive to alternative data frequencies, or to the inclusion of time fixed effects. Next, we examine whether our baseline results are robust to alternative measures of labor. Finally, we compute the standard errors using alternative bootstrapping methods.

\section{A. Alternative Data Frequencies}

The baseline results above are estimated based on 3-year averaged data. The reason for using 3 year averaging rather than annual frequency data is twofold: first, it mitigates the business-cycle effects and other potential noise in the annual frequency data and second, it provides large sample for consistent estimation. However, we recognize that the choice of 3-year averaging is arbitrary. To the best of our knowledge, there is no method to determine the optimal data frequency in the estimation of aggregate production functions. As a first robustness check, we investigate whether our baseline results are robust to alternative data frequencies.

Table 5 reports the coefficient estimates with 2- and 5-year averaged data. With 2-year averaging, the data are affected by the business cycle more while it has more observations; with 5-year averaging, the data are affected by the business cycle less while it has fewer observations. With different data frequencies, the estimated elasticity of substitution between private and public capital is generally robust. It is close to 3 for the complete sample, which is mainly driven by the emerging economies and it is insignificant for advanced economies. The estimated substitution coefficient between composed capital and labor $(\rho)$ is somewhat mixed, while it is insignificant in general. The distribution coefficients are still precisely estimated and are close to those in the baseline results. The estimated technology growth parameter $(\lambda)$ is higher with lower frequency data, while both are about 2 percent per year.

Given that in general, the capital-labor substitution parameter $(\rho)$ is not statistically different from zero, we further estimate the CES nested in Cobb-Douglas production function. As reported

in Table 6 , the estimated elasticity of substitution between public and private capital remains robust. The results are almost identical in the cases where the capital-labor substitution parameter $(\rho)$ is insignificant. For the cases where the capital-labor substitution parameter is significant, restricting it to zero results in a lower capital-labor distribution parameter. 


\section{B. Time Fixed Effects}

In the baseline estimation, we assume a constant and Hicks-neutral technical progress along time and there are no time fixed effects. One concern is that the technological growth rate can be changing over time, which can be an issue for our estimation considering that we use a large panel with a long time span. To address this concern, we include time fixed effects into the baseline estimates. Due to the complexities of NLLS estimation, the iterative optimization procedure has difficulties in converging when we include fixed effects for each single time period. As an alternate, we include time fixed effects for aggregate time periods.

Table 7 reports estimates when including time fixed effects with different frequencies. In panel (A), we include a dummy variable which equals 0 for the pre-1990 periods and 1 for the post-1990 periods. The estimated elasticity of substitution between private and public capital are very close to those in the baseline results. The estimated capital-labor substitution parameter remains negative and significant in the emerging economies and LIDCs. The distribution parameters are also generally robust. In panel (B), we include dummy variables for each 12 years. Results remain robust, except that the estimated private-public substitution for LIDCs becomes much larger, almost the same magnitude as that for the emerging economies.

Given that the capital-labor substitution parameter $(\rho)$ is statistically insignificant, we further estimate the CES nested in Cobb-Douglas production function. As reported in Table 8, the elasticity of substitution between public and private capital are very close to the baseline results as reported in Table 7. The only exception is that for the LIDCs, restricting the significant capitallabor elasticity parameter results in a larger private-public capital elasticity, with a point estimate close to 4.

\section{Controlling for Human Capital}

In the baseline estimates above, labor input is measured directly as total employment. One concern is that labor and labor income might not be properly measured, especially in emerging economies and LIDCs, as Gollin (2002) discussed. The mismeasure of labor input might affect the estimated elasticity of substitution and distribution between the composite capital and labor, and further affects the estimated elasticity of substitution between private and public capital. Krusell et al. (2000) find that the relative quantity of skilled labor has increased substantially since 1980, and 
controlling for capital-skill complementarity affects production function estimations. To address this concern, we weight total employment with human capital. The human capital index is retrieved directly from PWT, and it measures the average schooling and returns to education. Instead of including total employment, we multiply total employment with the human capital index.

Table 9 reports the NLLS estimates of the two-level CES production function on non-rolling 3-year averaged data. Limited by the human capital data availability, the number of observations decreases from 2,071 to 1,864 . The major impact of controlling for human capital is that the publicprivate capital substitution parameter becomes insignificant in LIDCs. Besides that, results remain robust: the estimated public-private capital substitution parameter $(\theta)$ and the share parameter $(b)$ are of similar magnitude and significance level for the full sample of countries and for different country groups. The capital-labor substitution parameter becomes insignificant in emerging economies. Not surprisingly, the capital share parameter $(a)$ and productivity growth $(\lambda)$ become smaller after controlling for human capital.

Given that the substitution parameter $(\rho)$ is statistically different from zero only in LIDCs, we further estimate the CES nested in Cobb-Douglas production function. As reported in Table 10, the elasticity of substitution between public and private capital remains robust: the results are almost identical for the full sample, advanced economies, and emerging economies. For LIDCs, setting the capital-labor substitution parameter to zero results in a lower capital-labor distribution parameter. The public-private capital substitution coefficient estimate reaches that of emerging economies, but is statistically insignificant.

\section{Bootstrapping Standard Errors}

In the baseline results, coefficients are estimated using the standard Levenberg-Marquardt nonlinear least squares algorithm and the standard deviations are calculated based on the Jacobian and mean square error. One concern is that the standard errors are not robust to different methods. To address this concern, we retrieve the standard errors from bootstrap estimation clustering at the country level.

Table 11 shows the estimated results. Standard errors in parenthesis are estimated based on 1000 bootstrapping simulations. The elasticity of substitution between private and public capital remains highly significant for the full sample and emerging economies. In addition, statistical 
significance improves for the LIDCs grouping. We also report the 16th-84th percentile confidence interval, which also shows that the estimated elasticity of substitution is significantly higher than unity, with an upper bound of around 7.2 for advanced economies. Figure 2 shows the distributions of the estimated elasticity of substitution by country group. The estimated distribution parameters remain statistically significant. Given that the elasticity of substitution between composite capital and labor $(\rho)$ becomes insignificant for all country groups, we conduct the same analysis for the CES nested in Cobb-Douglas production as done previously. Table 12 and Figure 3 show that baseline results are robust.

\section{E. Endogeneity}

In order to address concerns over endogeneity and transmission bias we next resort to macroeconometric techniques. For this purpose, we resort to a Kmenta (1967) linearized approximation to public-private capital CES nested in the Cobb-Douglas production function that allows the use of linear regression methods.

Panel unit root tests overwhelmingly fail to reject the unit root in all four variables of interest: real GDP, real private capital stock, real public capital stock and the square of a ratio of public to private capital (all expressed as ratios to employment and in natural logs). At the same time, a battery of panel cointegration tests due to Pedroni, Westerlund, and Kao reject the null hypothesis of no cointegration between all four variables decisively only for emerging economies; cointegration results for LIDC are more mixed whereas for advanced countries several test specifications fail to reject the null. Estimation results are therefore most meaningful for emerging countries. We estimate the parameters of the linearized Kmenta CES function with panel group mean FMOLS developed by Pedroni $(2000,2001)$ that allows for complete endogeneity (using internal instruments) as well as heterogeneity, and includes time effects to control for simple crosssectional dependence. The results support public-private capital substitutability for emerging countries as well as for the full sample. Results are available upon request.

In summary, we find strong evidence of substitutability between public and private capital, with a point estimate of the elasticity of substitution around 3. This result is driven by emerging economies and LIDCs, and it is more robust in emerging economies. For advanced economies, 
estimation shows no significant results. These results hold up pretty well to a series of robustness tests.

\section{Conclusion}

In this paper we find evidence against the perfect substitutability between public and private capital assumed in the literature. Using a nested CES aggregate production function that incorporates public and private capital along with labor as inputs, we obtain a point estimate of the elasticity of substitution between the two types of capital around 3. The estimation is based on a newly developed dataset on public and private capital stocks for 151 countries over a period of 1960 2014 consistent with Penn World Table version 9.

Our results provide some leads about growth policies. First, abstracting from other factors of production, high substitution between public and private capital implies that, as the capital stock increases, both marginal and average products approach to a positive constant, rather than zero as prescribed by Inada conditions. Second, the empirical estimates which show that public and private capital in the production of developing economies is more substitutable than in advanced countries, are consistent with the idea that advanced economic systems require provision of public capital that is more complementary to highly specialized private sector capital, while in less advanced countries public capital is needed to fill gaps in private sector which is still quite underdeveloped. While our estimates do not allow us to identify specific channels or causes of capital substitutability, we hope that they provide a starting point to a promising line of future research. 
Table 1. Summary Statistics

\begin{tabular}{ll|ccc|ccc}
\hline \multirow{2}{*}{ Country Group } & \multicolumn{3}{|c|}{ Investment (\% of GDP) } & \multicolumn{3}{c}{ Capital (\% of GDP) } \\
\hline \multirow{2}{*}{ All } & Statistics & Total & Private & Public & Total & Private & Public \\
\hline \multirow{2}{*}{ Advanced } & Mean & 26.5 & 18.7 & 7.7 & 325.2 & 213.0 & 112.2 \\
& St. Dev. & $(15.3)$ & $(12.1)$ & $(7.4)$ & $(192.0)$ & $(136.0)$ & $(111.8)$ \\
\multirow{2}{*}{ Emerging } & Mean & 31.8 & 25.8 & 6.1 & 385.9 & 297.0 & 88.9 \\
& St. Dev. & $(10.6)$ & $(8.5)$ & $(3.5)$ & $(128.2)$ & $(107.8)$ & $(38.0)$ \\
\multirow{2}{*}{ LIDCs } & Mean & 27.6 & 19.6 & 8.0 & 303.8 & 200.9 & 102.8 \\
& St. Dev. & $(14.9)$ & $(12.7)$ & $(6.0)$ & $(136.7)$ & $(116.7)$ & $(64.6)$ \\
& Mean & 21.6 & 13.3 & 8.3 & 320.8 & 181.4 & 139.4 \\
& St. Dev. & $(16.8)$ & $(10.3)$ & $(10.1)$ & $(268.9)$ & $(155.6)$ & $(172.6)$ \\
\hline
\end{tabular}

Sources: Penn World Table 9.0, IMF World Economic Outlook October 2016, and authors' estimates.

Table 2. Correlation of Growth Rates between Real GDP and Capital Stocks

\begin{tabular}{|c|c|c|c|c|c|c|c|c|}
\hline & \multicolumn{4}{|c|}{ All } & \multicolumn{4}{|c|}{ Advanced } \\
\hline & GDP & Total K & Private K & Public K & GDP & Total K & Private K & Public K \\
\hline GDP & 1 & & & & 1 & & & \\
\hline Total K & 0.36 & 1 & & & 0.54 & 1 & & \\
\hline Private K & 0.32 & 0.88 & 1 & & 0.53 & 0.99 & 1 & \\
\hline \multirow[t]{3}{*}{ Public K } & 0.26 & 0.72 & 0.42 & 1 & 0.50 & 0.91 & 0.84 & 1 \\
\hline & \multicolumn{4}{|c|}{ Emerging } & \multicolumn{4}{|c|}{ LIDCs } \\
\hline & GDP & Total K & Private K & Public K & GDP & Total K & Private K & Public K \\
\hline GDP & 1 & & & & 1 & & & \\
\hline Total K & 0.36 & 1 & & & 0.31 & 1 & & \\
\hline Private K & 0.31 & 0.88 & 1 & & 0.28 & 0.85 & 1 & \\
\hline Public K & 0.24 & 0.65 & 0.32 & 1 & 0.24 & 0.77 & 0.44 & 1 \\
\hline
\end{tabular}

Sources: Penn World Table 9.0, IMF World Economic Outlook October 2016, and authors' estimates. 
Table 3. Two-level CES, Non-linear Least

\begin{tabular}{l|cccc}
\hline & All & Adv & Eme & LIDCs \\
& {$[1]$} & {$[2]$} & {$[3]$} & {$[4]$} \\
\hline$\theta$ & $0.66^{* * *}$ & 0.25 & $0.71^{* * *}$ & $0.53^{*}$ \\
& $(0.16)$ & $(1.29)$ & $(0.21)$ & $(0.31)$ \\
$b$ & $0.56^{* * *}$ & $0.64^{* *}$ & $0.50^{* * *}$ & $0.58^{* * *}$ \\
& $(0.04)$ & $(0.32)$ & $(0.05)$ & $(0.08)$ \\
$\rho$ & -0.02 & -0.13 & $-0.27^{* *}$ & $-0.28^{*}$ \\
& $(0.06)$ & $(0.11)$ & $(0.13)$ & $(0.15)$ \\
$a$ & $0.61^{* * *}$ & $0.60^{* * *}$ & $0.84^{* * *}$ & $0.61^{* * *}$ \\
& $(0.04)$ & $(0.10)$ & $(0.07)$ & $(0.07)$ \\
$\lambda(\%)$ & $0.75^{* * *}$ & $2.7 * * *$ & -0.15 & $0.77^{*}$ \\
& $(0.27)$ & $(0.53)$ & $(0.45)$ & $(0.46)$ \\
ES & 2.94 & 1.33 & 3.45 & 2.13 \\
& {$[1.54,4.34]$} & {$[-0.96,3.62]$} & {$[0.93,5.97]$} & {$[0.75,3.51]$} \\
\hline Obs & 2071 & 438 & 981 & 652 \\
R-sq & 0.32 & 0.59 & 0.31 & 0.26 \\
\hline Sour & P. Pes &
\end{tabular}

Sources: Penn World Table 9.0, IMF World Economic Outlook October 2016, and authors' estimates. Note: Dependent variable is the growth rate of averaged GDP. Standard errors in parentheses are recovered using standard approximation methods. Significant at $* 10 \%, * * 5 \%, * * * 1 \%$. Elasticity of substitution between public and private capital (ES) is calculated as $1 /(1-\theta)$. One standard deviation confidence intervals in brackets are derived using the delta method.

Table 4. CES-nested-in-CD, Non-linear Least Squares

\begin{tabular}{l|cccc}
\hline & All & Adv & Eme & LIDCs \\
& {$[1]$} & {$[2]$} & {$[3]$} & {$[4]$} \\
\hline$\theta$ & $0.66^{* * *}$ & 0.46 & $0.70^{* * *}$ & $0.62^{* *}$ \\
& $(0.16)$ & $(1.24)$ & $(0.21)$ & $(0.30)$ \\
$b$ & $0.56^{* * *}$ & $0.62^{* *}$ & $0.52^{* * *}$ & $0.61^{* * *}$ \\
& $(0.04)$ & $(0.31)$ & $(0.05)$ & $(0.07)$ \\
$a$ & $0.60^{* * *}$ & $0.50^{* * *}$ & $0.68^{* * *}$ & $0.50^{* * *}$ \\
& $(0.02)$ & $(0.04)$ & $(0.03)$ & $(0.04)$ \\
$\lambda(\%)$ & $0.74^{* * *}$ & $2.43^{* * *}$ & -0.07 & $0.90^{* *}$ \\
& $(0.27)$ & $(0.48)$ & $(0.45)$ & $(0.45)$ \\
ES & 2.94 & 1.85 & 3.33 & 2.63 \\
& {$[1.54,4.34]$} & {$[-2.41,6.11]$} & {$[0.95,5.71]$} & {$[0.53,4.73]$} \\
\hline Obs & 2071 & 438 & 981 & 652 \\
R-sq & 0.32 & 0.59 & 0.31 & 0.26 \\
\hline
\end{tabular}

Sources: Penn World Table 9.0, IMF World Economic Outlook October 2016, and authors' estimates. Note: Dependent variable is the growth rate of averaged GDP. Standard errors in parentheses are recovered using standard approximation methods. Significant at $* 10 \%, * * 5 \%, * * * 1 \%$. Elasticity of substitution between public and private capital (ES) is calculated as $1 /(1-\theta)$. One standard deviation confidence intervals in brackets are derived using the delta method. 
Table 5. Two-level CES, Alternative Data Frequencies

\begin{tabular}{|c|c|c|c|c|c|c|c|c|}
\hline & \multicolumn{4}{|c|}{ (A) 2-year Average } & \multicolumn{4}{|c|}{ (B) 5-year Average } \\
\hline & $\begin{array}{l}\text { All } \\
{[1]}\end{array}$ & $\begin{array}{l}\text { Adv } \\
{[2]}\end{array}$ & $\begin{array}{c}\text { Eme } \\
{[3]}\end{array}$ & $\begin{array}{c}\text { LIDCs } \\
{[4]}\end{array}$ & $\begin{array}{l}\text { All } \\
{[5]}\end{array}$ & $\begin{array}{c}\text { Adv } \\
{[6]}\end{array}$ & $\begin{array}{c}\text { Eme } \\
{[7]}\end{array}$ & $\begin{array}{c}\text { LIDCs } \\
{[8]}\end{array}$ \\
\hline$\theta$ & $\begin{array}{c}0.61 * * * \\
(0.15)\end{array}$ & $\begin{array}{c}0.16 \\
(1.11)\end{array}$ & $\begin{array}{c}0.66^{* * * *} \\
(0.21)\end{array}$ & $\begin{array}{l}0.58 * * \\
(0.26)\end{array}$ & $\begin{array}{c}0.64 * * * \\
(0.16)\end{array}$ & $\begin{array}{l}-0.55 \\
(1.38)\end{array}$ & $\begin{array}{c}0.68 * * * \\
(0.20)\end{array}$ & $\begin{array}{l}0.60^{*} \\
(0.37)\end{array}$ \\
\hline$b$ & $\begin{array}{c}0.57^{* * * *} \\
(0.03)\end{array}$ & $\begin{array}{l}0.56^{*} \\
(0.30)\end{array}$ & $\begin{array}{c}0.55^{* * *} \\
(0.05)\end{array}$ & $\begin{array}{c}0.62 * * * \\
(0.06)\end{array}$ & $\begin{array}{c}0.53 * * * \\
(0.04)\end{array}$ & $\begin{array}{c}0.83^{* * *} * \\
(0.23)\end{array}$ & $\begin{array}{c}0.47 * * * \\
(0.05)\end{array}$ & $\begin{array}{c}0.57 * * * \\
(0.09)\end{array}$ \\
\hline$\rho$ & $\begin{array}{c}0.08 \\
(0.05)\end{array}$ & $\begin{array}{l}-0.19^{*} \\
(0.11)\end{array}$ & $\begin{array}{l}-0.09 \\
(0.11)\end{array}$ & $\begin{array}{l}-0.03 \\
(0.12)\end{array}$ & $\begin{array}{c}0.03 \\
(0.06)\end{array}$ & $\begin{array}{l}-0.01 \\
(0.11)\end{array}$ & $\begin{array}{c}-0.33^{* *} \\
(0.14)\end{array}$ & $\begin{array}{l}-0.24 \\
(0.16)\end{array}$ \\
\hline$a$ & $\begin{array}{c}0.50 * * * \\
(0.04)\end{array}$ & $\begin{array}{c}0.62 * * * \\
(0.09)\end{array}$ & $\begin{array}{c}0.70 * * * \\
(0.09)\end{array}$ & $\begin{array}{c}0.48 * * * \\
(0.06)\end{array}$ & $\begin{array}{c}0.59 * * * \\
(0.04)\end{array}$ & $\begin{array}{c}0.58 * * * \\
(0.09)\end{array}$ & $\begin{array}{c}0.87 * * * \\
(0.06)\end{array}$ & $\begin{array}{c}0.57 * * * \\
(0.07)\end{array}$ \\
\hline$\lambda(\%)$ & $\begin{array}{c}0.37 * * \\
(0.16)\end{array}$ & $\begin{array}{c}1.87 * * * \\
(0.31)\end{array}$ & $\begin{array}{l}-0.09 \\
(0.27)\end{array}$ & $\begin{array}{c}0.34 \\
(0.25)\end{array}$ & $\begin{array}{c}1.39 * * * \\
(0.42)\end{array}$ & $\begin{array}{c}3.05 * * * \\
(0.80)\end{array}$ & $\begin{array}{l}-0.05 \\
(0.67)\end{array}$ & $\begin{array}{c}1.65^{* *} \\
(0.74)\end{array}$ \\
\hline ES & $\begin{array}{c}2.56 \\
{[1.60,3.52]}\end{array}$ & $\begin{array}{c}1.19 \\
{[-0.38,2.76]}\end{array}$ & $\begin{array}{c}2.94 \\
{[1.15,4.73]}\end{array}$ & $\begin{array}{c}2.38 \\
{[0.93,3.83]}\end{array}$ & $\begin{array}{c}2.78 \\
{[1.52,4.04]}\end{array}$ & $\begin{array}{c}0.65 \\
{[0.08,1.22]}\end{array}$ & $\begin{array}{c}3.13 \\
{[1.14,5.12]}\end{array}$ & $\begin{array}{c}2.50 \\
{[0.18,4.82]}\end{array}$ \\
\hline Obs & 3152 & 664 & 1495 & 993 & 1331 & 283 & 630 & 418 \\
\hline R-sq & 0.25 & 0.50 & 0.21 & 0.23 & 0.40 & 0.70 & 0.40 & 0.30 \\
\hline
\end{tabular}

Sources: Penn World Table 9.0, IMF World Economic Outlook October 2016, and authors' estimates.

Note: Dependent variable is the growth rate of averaged GDP. Standard errors in parentheses are recovered using standard approximation methods. Significant at $* 10 \%, * * 5 \%, * * * 1 \%$. Elasticity of substitution between public and private capital (ES) is calculated as $1 /(1-\theta)$. One standard deviation confidence intervals in brackets are derived using the delta method.

Table 6. CES-nested-in-CD, Alternative Data Frequencies

\begin{tabular}{l|cccc|cccc}
\hline & \multicolumn{5}{|c|}{ (A) 2-year Average } & \multicolumn{4}{c}{ (B) 5-year Average } \\
& All & Adv & Eme & LIDCs & All & Adv & Eme & LIDCs \\
& {$[1]$} & {$[2]$} & {$[3]$} & {$[4]$} & {$[5]$} & {$[6]$} & {$[7]$} & {$[8]$} \\
\hline$\theta$ & $0.62^{* * *}$ & 0.36 & $0.65^{* * *}$ & $0.60^{* *}$ & $0.63 * * *$ & -0.51 & $0.65^{* * *}$ & $0.69^{*}$ \\
& $(0.15)$ & $(1.03)$ & $(0.21)$ & $(0.25)$ & $(0.16)$ & $(1.32)$ & $(0.20)$ & $(0.37)$ \\
$b$ & $0.57 * * *$ & $0.55^{* *}$ & $0.55^{* * *}$ & $0.62^{* * *}$ & $0.53 * * *$ & $0.83 * * *$ & $0.48^{* * *}$ & $0.60^{* * *}$ \\
& $(0.03)$ & $(0.28)$ & $(0.05)$ & $(0.06)$ & $(0.04)$ & $(0.23)$ & $(0.05)$ & $(0.09)$ \\
$a$ & $0.56^{* * *}$ & $0.47 * * *$ & $0.63 * * *$ & $0.47 * * *$ & $0.61 * * *$ & $0.57 * * *$ & $0.70^{* * *}$ & $0.48^{* * *}$ \\
& $(0.02)$ & $(0.03)$ & $(0.03)$ & $(0.03)$ & $(0.02)$ & $(0.04)$ & $(0.03)$ & $(0.04)$ \\
$\lambda(\%)$ & $0.39 * * *$ & $1.65^{* * *}$ & -0.07 & 0.35 & $1.41 * * *$ & $3.02^{* * *}$ & 0.03 & $1.83^{* * *}$ \\
& $(0.16)$ & $(0.29)$ & $(0.26)$ & $(0.25)$ & $(0.42)$ & $(0.71)$ & $(0.67)$ & $(0.73)$ \\
ES & 2.63 & 1.56 & 2.86 & 2.50 & 2.70 & 0.66 & 2.86 & 3.23 \\
& {$[1.62,3.64]$} & $-0.96,4.08]$ & {$[1.18,4.54]$} & {$[0.91,4.09]$} & {$[1.51,3.89]$} & {$[0.08,1.24]$} & {$[1.19,4.53]$} & {$[-0.58,7.04]$} \\
\hline Obs & 3152 & 664 & 1495 & 993 & 1331 & 283 & 630 & 418 \\
R-sq & 0.25 & 0.50 & 0.21 & 0.23 & 0.40 & 0.70 & 0.39 & 0.30 \\
\hline
\end{tabular}

Sources: Penn World Table 9.0, IMF World Economic Outlook October 2016, and authors' estimates.

Note: Dependent variable is the growth rate of averaged GDP. Standard errors in parentheses are recovered using standard approximation methods. Significant at $* 10 \%, * * 5 \%, * * * 1 \%$. Elasticity of substitution between public and private capital (ES) is calculated as $1 /(1-\theta)$. One standard deviation confidence intervals in brackets are derived using the delta method. 
Table 7. CES-nested-in-CD, with Time Fixed Effects

\begin{tabular}{l|cccc|cccc}
\hline & \multicolumn{3}{|c}{ (A) Dummy for Pre- and Post-1990 } & \multicolumn{4}{c}{ (B) Dummies for Every 12 Years } \\
& All & Adv & Eme & LIDCs & All & Adv & Eme & LIDCs \\
& {$[1]$} & {$[2]$} & {$[3]$} & {$[4]$} & {$[5]$} & {$[6]$} & {$[7]$} & {$[8]$} \\
\hline$\theta$ & $0.67 * * *$ & -0.16 & $0.73^{* * *}$ & $0.57 *$ & $0.67^{* * *}$ & -0.52 & $0.74 * * *$ & $0.67 *$ \\
& $(0.16)$ & $(1.59)$ & $(0.21)$ & $(0.32)$ & $(0.17)$ & $(1.91)$ & $(0.22)$ & $(0.38)$ \\
$b$ & $0.55^{* * *}$ & $0.77^{* *}$ & $0.49^{* * *}$ & $0.56^{* * *}$ & $0.55^{* * *}$ & $0.85^{* * *}$ & $0.49^{* * *}$ & $0.53^{* * *}$ \\
& $(0.04)$ & $(0.32)$ & $(0.05)$ & $(0.08)$ & $(0.04)$ & $(0.30)$ & $(0.06)$ & $(0.09)$ \\
$\rho$ & -0.02 & -0.08 & $-0.29^{* *}$ & $-0.31^{* *}$ & -0.02 & -0.05 & $-0.28^{* *}$ & $-0.35^{* *}$ \\
& $(0.06)$ & $(0.11)$ & $(0.14)$ & $(0.16)$ & $(0.06)$ & $(0.11)$ & $(0.13)$ & $(0.16)$ \\
$a$ & $0.61 * * *$ & $0.53^{* * *}$ & $0.85^{* * *}$ & $0.61 * * *$ & $0.59 * * *$ & $0.48^{* * *}$ & $0.83 * * *$ & $0.58^{* * *}$ \\
& $(0.04)$ & $(0.10)$ & $(0.06)$ & $(0.07)$ & $(0.04)$ & $(0.10)$ & $(0.07)$ & $(0.07)$ \\
ES & 3.03 & 0.86 & 3.70 & 2.33 & 3.23 & 0.66 & 3.85 & 3.03 \\
& {$[1.53,4.53]$} & {$[-0.32,2.04]$} & {$[0.76,6.64]$} & {$[0.6,4.06]$} & {$[1.47,4.99]$} & {$[-0.17,1.49]$} & {$[0.61,7.09]$} & {$[-0.45,6.51]$} \\
\hline Obs & 2071 & 438 & 981 & 652 & 2071 & 438 & 981 & 652 \\
R-sq & 0.32 & 0.60 & 0.31 & 0.27 & 0.34 & 0.61 & 0.34 & 0.30 \\
\hline
\end{tabular}

Sources: Penn World Table 9.0, IMF World Economic Outlook October 2016, and authors' estimates.

Note: Dependent variable is the growth rate of averaged GDP. Standard errors in parentheses are recovered using standard approximation methods. Significant at $* 10 \%, * * 5 \%, * * * 1 \%$. Elasticity of substitution between public and private capital (ES) is calculated as $1 /(1-\theta)$. One standard deviation confidence intervals in brackets are derived using the delta method.

Table 8. Two-level CES, with Time Fixed Effects

\begin{tabular}{l|cccc|cccc}
\hline & \multicolumn{4}{|c}{ (A) Dummy for Pre- and Post-1990 } & \multicolumn{4}{c}{ (B) Dummies for Every 12 Years } \\
& All & Adv & Eme & LIDCs & All & Adv & Eme & LIDCs \\
& {$[1]$} & {$[2]$} & {$[3]$} & {$[4]$} & {$[5]$} & {$[6]$} & {$[7]$} & {$[8]$} \\
\hline$\theta$ & $0.67 * * *$ & -0.03 & $0.71 * * *$ & $0.65^{* *}$ & $0.69^{* * *}$ & -0.46 & $0.72 * * *$ & $0.75^{* *}$ \\
& $(0.16)$ & $(1.54)$ & $(0.22)$ & $(0.31)$ & $(0.17)$ & $(1.85)$ & $(0.22)$ & $(0.37)$ \\
$b$ & $0.55^{* * *}$ & $0.77^{* *}$ & $0.51^{* * *}$ & $0.6^{* * *}$ & $0.55^{* * *}$ & $0.85^{* * *}$ & $0.50^{* * *}$ & $0.58^{* * *}$ \\
& $(0.04)$ & $(0.32)$ & $(0.05)$ & $(0.08)$ & $(0.04)$ & $(0.30)$ & $(0.05)$ & $(0.08)$ \\
$a$ & $0.60^{* * *}$ & $0.46^{* * *}$ & $0.69 * * *$ & $0.49^{* * *}$ & $0.58^{* * *}$ & $0.44 * * *$ & $0.67 * * *$ & $0.45^{* * *}$ \\
& $(0.02)$ & $(0.04)$ & $(0.03)$ & $(0.04)$ & $(0.02)$ & $(0.04)$ & $(0.03)$ & $(0.04)$ \\
ES & 3.03 & 0.97 & 3.45 & 2.86 & 3.23 & 0.68 & 3.57 & 4.00 \\
& {$[1.53,4.53]$} & {$[-0.48,2.42]$} & {$[0.88,6.02]$} & {$[0.31,5.41]$} & {$[1.47,4.99]$} & {$[-0.19,1.55]$} & {$[0.77,6.37]$} & {$[-1.84,9.84]$} \\
\hline Obs & 2071 & 438 & 981 & 652 & 2071 & 438 & 981 & 652 \\
R-sq & 0.32 & 0.6 & 0.31 & 0.26 & 0.34 & 0.61 & 0.33 & 0.29 \\
\hline
\end{tabular}

Sources: Penn World Table 9.0, IMF World Economic Outlook October 2016, and authors' estimates.

Note: Dependent variable is the growth rate of averaged GDP. Standard errors in parentheses are recovered using standard approximation methods. Significant at $* 10 \%, * * 5 \%, * * * 1 \%$. Elasticity of substitution between public and private capital (ES) is calculated as $1 /(1-\theta)$. One standard deviation confidence intervals in brackets are derived using the delta method. 
Table 9. Two-level CES, Control for Human Capital, NLLS

\begin{tabular}{l|cccc}
\hline & All & Adv & Eme & LIDCs \\
& {$[1]$} & {$[2]$} & {$[3]$} & {$[4]$} \\
\hline$\theta$ & $0.65^{* * *}$ & 0.38 & $0.64^{* * *}$ & 0.46 \\
& $(0.20)$ & $(1.25)$ & $(0.25)$ & $(0.34)$ \\
& $0.54^{* * *}$ & $0.61^{*}$ & $0.51^{* * *}$ & $0.51^{* * *}$ \\
$\rho$ & $(0.04)$ & $(0.32)$ & $(0.06)$ & $(0.09)$ \\
& 0.00 & 0.02 & -0.15 & $-0.44^{* *}$ \\
$a$ & $(0.07)$ & $(0.12)$ & $(0.15)$ & $(0.2)$ \\
& $0.58^{* * *}$ & $0.46^{* * *}$ & $0.74^{* * *}$ & $0.63^{* * *}$ \\
$\lambda(\%)$ & $(0.04)$ & $(0.09)$ & $(0.09)$ & $(0.07)$ \\
& -0.36 & $1.38^{* * *}$ & $-1.06^{* * *}$ & $-0.92^{*}$ \\
ES & $(0.25)$ & $(0.44)$ & $(0.41)$ & $(0.50)$ \\
& 2.86 & 1.61 & 2.78 & 1.85 \\
& {$[1.21,4.51]$} & {$[-1.64,4.86]$} & {$[0.86,4.70]$} & {$[0.67,3.03]$} \\
\hline Obs & 1864 & 438 & 848 & 578 \\
R-sq & 0.28 & 0.6 & 0.22 & 0.24 \\
\hline Sol & & &
\end{tabular}

Sources: Penn World Table 9.0, IMF World Economic Outlook October 2016, and authors' estimates. Note: Dependent variable is the growth rate of averaged GDP. Labor input is measured as total employment weighted by human capital. Standard errors in parentheses are recovered using standard approximation methods. Significant at $* 10 \%, * * 5 \%, * * * 1 \%$. Elasticity of substitution between public and private capital (ES) is calculated as $1 /(1-\theta)$. One standard deviation confidence intervals in brackets are derived using the delta method.

Table 10. CES-nested-in-CD, Control for Human Capital, NLLS

\begin{tabular}{l|cccc}
\hline & All & Adv & Eme & LIDCs \\
& {$[1]$} & {$[2]$} & {$[3]$} & {$[4]$} \\
\hline$\theta$ & $0.65^{* * *}$ & 0.36 & $0.64^{* * *}$ & 0.66 \\
& $(0.20)$ & $(1.24)$ & $(0.25)$ & $(0.43)$ \\
$b$ & $0.54^{* * *}$ & $0.61^{*}$ & $0.51^{* * *}$ & $0.56^{* * *}$ \\
& $(0.04)$ & $(0.32)$ & $(0.06)$ & $(0.09)$ \\
$a$ & $0.58^{* * *}$ & $0.46^{* * *}$ & $0.65^{* * *}$ & $0.51^{* * *}$ \\
& $(0.02)$ & $(0.04)$ & $(0.04)$ & $(0.04)$ \\
$\lambda(\%)$ & -0.36 & $1.39^{* * *}$ & $-0.95^{* *}$ & -0.50 \\
& $(0.25)$ & $(0.42)$ & $(0.39)$ & $(0.49)$ \\
ES & 2.86 & 1.56 & 2.78 & 2.94 \\
& {$[1.21,4.51]$} & {$[-1.46,4.58]$} & {$[0.85,4.71]$} & {$[-0.76,6.64]$} \\
\hline Obs & 1864 & 438 & 848 & 578 \\
R-sq & 0.28 & 0.60 & 0.22 & 0.24 \\
\hline
\end{tabular}

Sources: Penn World Table 9.0, IMF World Economic Outlook October 2016, and authors' estimates. Note: Dependent variable is the growth rate of averaged GDP. Labor input is measured as total employment weighted by human capital. Standard errors in parentheses are recovered using standard approximation methods. Significant at $* 10 \%, * * 5 \%, * * * 1 \%$. Elasticity of substitution between public and private capital (ES) is calculated as $1 /(1-\theta)$. One standard deviation confidence intervals in brackets are derived using the delta method. 
Table 11: Two-level CES, Bootstrapping

\begin{tabular}{l|cccc}
\hline & All & Adv & Eme & LIDCs \\
& {$[1]$} & {$[2]$} & {$[3]$} & {$[4]$} \\
\hline$\theta$ & $0.66^{* * *}$ & 0.25 & $0.71^{* * *}$ & $0.53^{* *}$ \\
& $(0.17)$ & $(0.60)$ & $(0.18)$ & $(0.21)$ \\
& $0.56^{* * *}$ & $0.64^{* * *}$ & $0.50^{* * *}$ & $0.58^{* * *}$ \\
$\rho$ & $(0.04)$ & $(0.16)$ & $(0.05)$ & $(0.09)$ \\
& -0.02 & -0.13 & -0.27 & -0.28 \\
$a$ & $(0.09)$ & $(0.11)$ & $(0.20)$ & $(0.25)$ \\
& $0.61^{* * *}$ & $0.60^{* * *}$ & $0.84^{* * *}$ & $0.61^{* * *}$ \\
$\lambda(\%)$ & $(0.07)$ & $(0.10)$ & $(0.10)$ & $(0.11)$ \\
& $0.75^{* *}$ & $2.70^{* * *}$ & -0.15 & $0.77^{*}$ \\
ES & $(0.32)$ & $(0.74)$ & $(0.54)$ & $(0.48)$ \\
& 2.94 & 1.33 & 3.45 & 2.13 \\
& {$[1.63,3.61]$} & {$[1.44,7.27]$} & {$[1.73,4.59]$} & {$[1.46,3.85]$} \\
\hline Obs & 2071 & 438 & 981 & 652 \\
R-sq & 0.32 & 0.59 & 0.31 & 0.26 \\
\hline So & & &
\end{tabular}

Sources: Penn World Table 9.0, IMF World Economic Outlook October 2016, and authors' estimates. Note: Dependent variable is the growth rate of averaged GDP. Standard errors in parentheses and the one standard deviation confidence intervals from median in brackets are retrieved from 1000 bootstrapping simulations. Significant at $* 10 \%, * * 5 \%$, and $* * * 1 \%$.

Table 12: CES-nested-in-CD, Bootstrapping

\begin{tabular}{l|cccc}
\hline & All & Adv & Eme & LIDCs \\
& {$[1]$} & {$[2]$} & {$[3]$} & {$[4]$} \\
\hline$\theta$ & $0.66^{* * *}$ & 0.46 & $0.70^{* * *}$ & $0.62^{* * *}$ \\
& $(0.16)$ & $(0.41)$ & $(0.19)$ & $(0.19)$ \\
$b$ & $0.56^{* * *}$ & $0.62^{* * *}$ & $0.52^{* * *}$ & $0.61^{* * *}$ \\
& $(0.04)$ & $(0.16)$ & $(0.05)$ & $(0.06)$ \\
$a$ & $0.60^{* * *}$ & $0.50^{* * *}$ & $0.68^{* * *}$ & $0.5 * * *$ \\
& $(0.03)$ & $(0.04)$ & $(0.05)$ & $(0.04)$ \\
$\lambda(\%)$ & $0.74^{* *}$ & $2.43^{* * *}$ & -0.07 & $0.90 * *$ \\
& $(0.32)$ & $(0.59)$ & $(0.52)$ & $(0.47)$ \\
ES & 2.94 & 1.85 & 3.33 & 2.63 \\
& {$[1.66,3.55]$} & {$[1.06,8.51]$} & {$[1.54,4.01]$} & {$[1.66,4.93]$} \\
\hline Obs & 2071 & 438 & 981 & 652 \\
R-sq & 0.32 & 0.59 & 0.31 & 0.26 \\
\hline
\end{tabular}

Sources: Penn World Table 9.0, IMF World Economic Outlook October 2016, and authors' estimates. Note: Dependent variable is the growth rate of averaged GDP. Standard errors in parentheses and the one standard deviation confidence intervals from median in brackets are retrieved from 1000 bootstrapping simulations. Significant at $* 10 \%, * * 5 \%$, and $* * * 1 \%$. 
Figure 1: Investment Ratio and Growth Rate of Capital

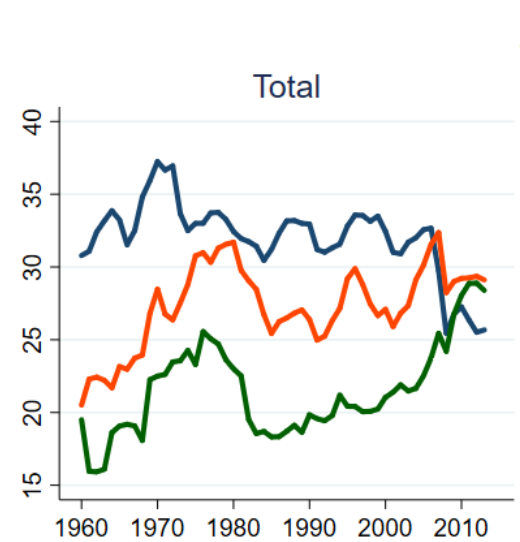

Average Investment (\% of GDP)
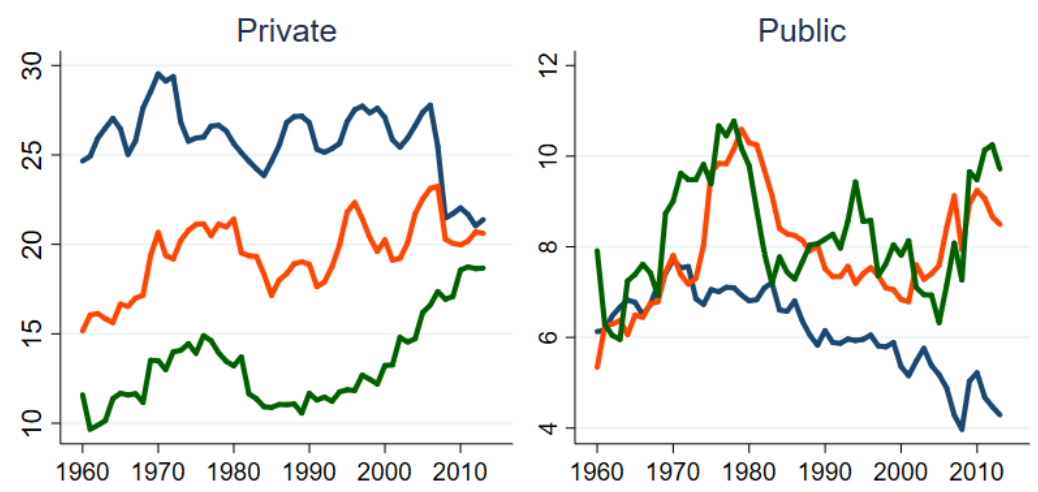

\section{Average Capital Growth (\%)}
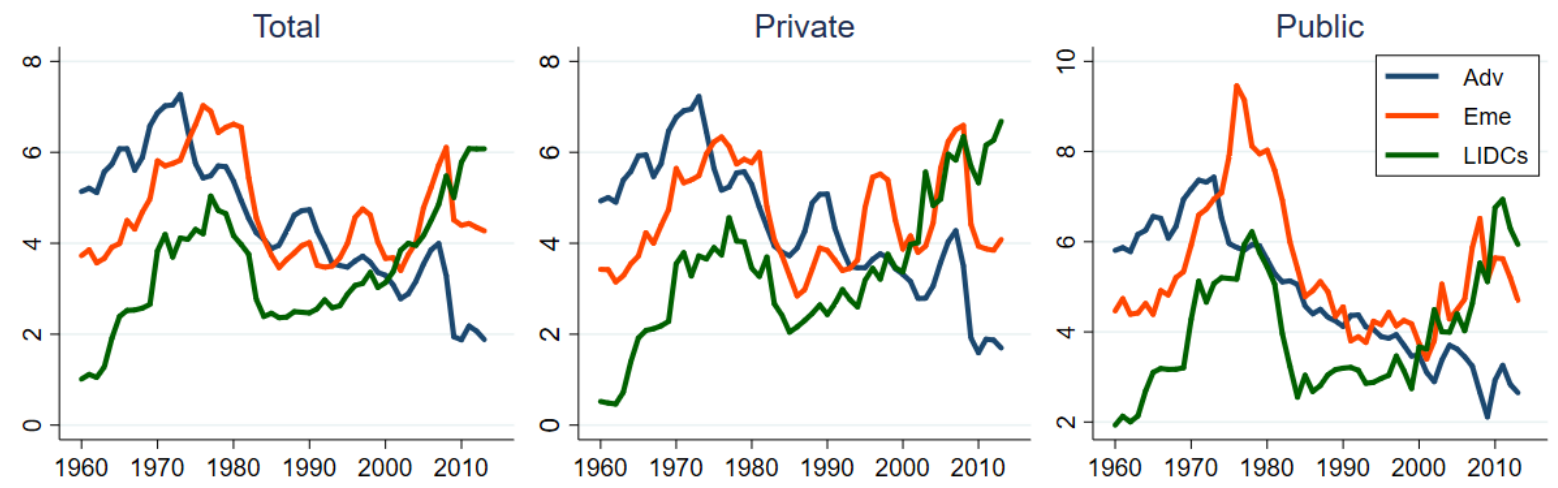

Sources: Penn World Table 9.0, IMF World Economic Outlook October 2016, and authors' estimates. 
Figure 2. Elasticity of Substitution between Private and Public Capital,

Bootstrapping of Two-level CES
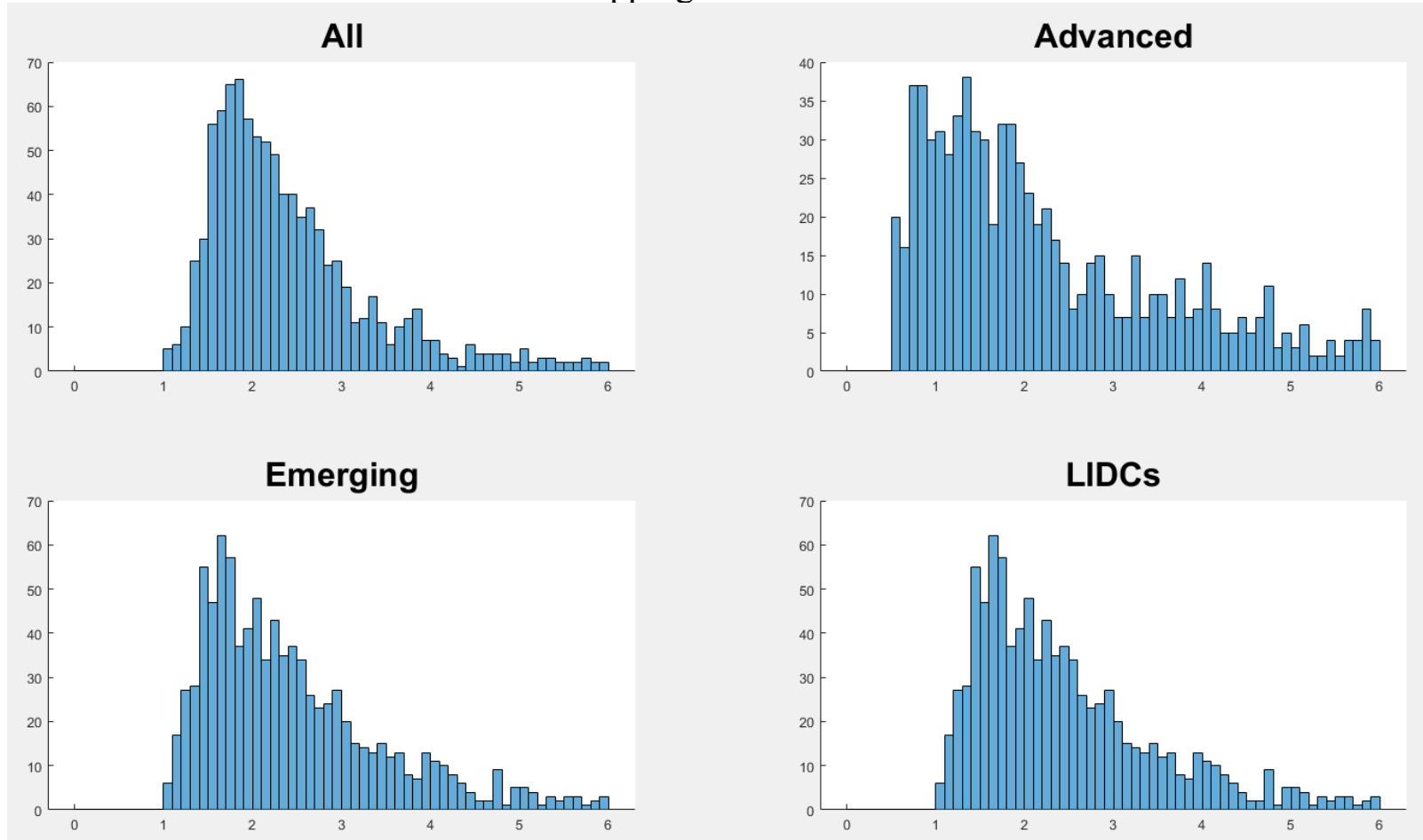

Sources: Penn World Table 9.0, IMF World Economic Outlook October 2016, and authors' estimates. 
Figure 3. Elasticity of Substitution between Private and Public Capital,

Bootstrapping of CES-CD
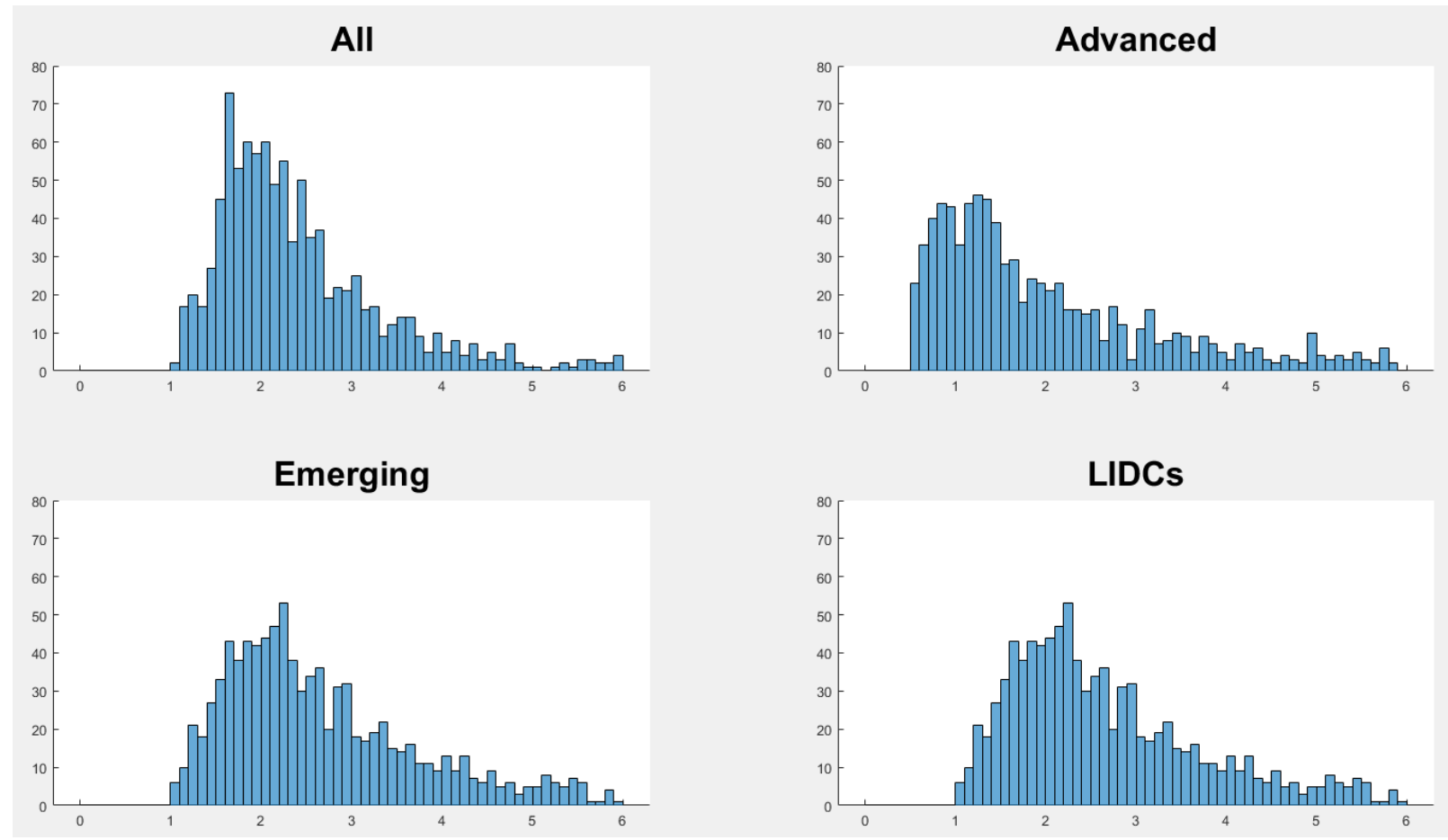

Sources: Penn World Table 9.0, IMF World Economic Outlook October 2016, and authors' estimates. 


\section{REFERENCES}

[1] Agénor, P. R. (2010). A theory of infrastructure-led development. Journal of Economic Dynamics and Control 34(5), 932-950.

[2] Agénor, P. R. (2012). Public Capital, Growth and Welfare: Analytical Foundations for Public Policy. Princeton, NJ: Princeton University Press.

[3] Arrow, K. J., H. B. Chenery, B. S. Minhas, and R. M. Solow (1961). Capital-labor substitution and economic efficiency. Review of Economics and Statistics 43(3), 225-250.

[4] Arslanalp, S., F. Bornhorst, S. Gupta, and E. Sze (2010). Public capital and growth. IMF Working Paper No. 10/175.

[5] Aschauer, D. (1989). Is public expenditure productive? Journal of Monetary Economics 23(2), 177-200.

[6] Bom, P. R. and J. E. Lighthart (2014). What have we learned from three decades of research on the productivity of public capital? Journal of Economic Surveys 28(5), 889-916.

[7] Calderón, C., E. Moral-Benito, and L. Servén (2015). Is infrastructure capital productive? A dynamic heterogeneous approach. Journal of Applied Econometrics 30(2), 177-198.

[8] Caselli, F. (2005). Accounting for cross-country income differences. In P. Aghion and S. Durlauf (Eds.), Handbook of Economic Growth, Volume 1, pp. 679-741. Amsterdam, Netherlands: Elsevier.

[9] Caselli, F. and J. Feyrer (2007). The marginal product of capital. Quarterly Journal of Economics 122(2), 535-568.

[10] Caselli, F. and D. J. Wilson (2004). Importing technology. Journal of Monetary Economics 51(1), 1-32.

[11] Chatterjee, S. and S. J. Turnovsky (2012). Infrastructure and inequality. European Economic Review 56(8), 1730-1745.

[12] Chirinko, R. S. (2008). $\sigma$ : The long and short of it. Journal of Macroeconomics 30(2), 671-686. 
[13] Collier, P., A. Hoeffler, and C. Pattillo (2001). Flight capital as a portfolio choice. World Bank Economic Review 15(1), 55-80.

[14] Dabla-Norris, E., Brumby, J., Kyobe, A., Mills, Z., \& Papageorgiou, C. (2012). Investing in public investment: an index of public investment efficiency. Journal of Economic Growth, 17(3), 235-266.

[15] Dobbs, R., H. Pohl, D. Y. Lin, J. Mischke, N. Garemo, J. Hexter, S. Matzinger, R. Palter, and R. Nanavatty (2013). Infrastructure productivity: How to save $\$ 1$ trillion a year. McKinsey Global Institute 88.

[16] Duffy, J. and C. Papageorgiou (2000). A cross-country empirical investigation of the aggregate production function specification. Journal of Economic Growth 5(1), 87-120.

[17] Duffy, J., C. Papageorgiou, and F. Perez-Sebastian (2006). Capital-skill complementarity? Evidence from a panel of countries. Review of Economics and Statistics $86,327-344$.

[18] Feenstra, R. C., R. Inklaar, and M. P. Timmer (2015). The next generation of the Penn World Table. American Economic Review 105(10), 3150-3182.

[19] Fraumeni, B. (1997). The measurement of depreciation in the U.S. national income and product accounts. Survey of Current Business 77, 9-23.

[20] Gollin, D. (2002). Getting income shares right. Journal of Political Economy 110(2), 458-474.

[21] Gomme, P. and P. Rupert (2004). Measuring labor's share of income. FRB of Cleveland Policy Discussion Paper No. 7.

[22] Gomme, P. and P. Rupert (2007). Theory, measurement and calibration of macroeconomic models. Journal of Monetary Economics 54(2), 460-497.

[23] Gupta, S., A. Kangur, C. Papageorgiou, and A. Wane (2014). Efficiency-adjusted public capital and growth. World Development 57, 164-178.

[24] Hulten, C. and F. Wykoff (1981). The estimation of economic depreciation using vintage asset prices: An application of the Box-Cox power transformation. Journal of Econometrics 15(3), 367-396. 
[25] International Monetary Fund (2015). Making public investment more efficient.

[26] International Monetary Fund (2017). World Economic Outlook April 2017, Chapter 3: Understanding the downward trend in labor income shares.

[27] Kamps, C. (2006). New estimates of government net capital stocks for 22 OECD countries, 1960-2001. IMF Staff Papers 53(1), 120-150.

[28] Kangur, A. and C. Papageorgiou (2017). Public sector investment efficiency in developing countries. In The New Palgrave Dictionary of Economics, pp. 1-10. London, UK: Palgrave Macmillan.

[29] Karabarbounis, L. and B. Neiman (2013). The global decline of the labor share. Quarterly Journal of Economics 129(1), 61-103.

[30] Kmenta, J. (1967). On estimation of the CES production function. International Economic Review 8(2), 180-189.

[31] Koesler, S. and M. Schymura (2015). Substitution elasticities in a constant elasticity of substitution framework-empirical estimates using nonlinear least squares. Economic Systems Research 27 (1), 101-121.

[32] Krusell, P., L. E. Ohanian, J.-V. Ríos-Rull, and G. L. Violante (2000). Capital-skill complementarity and inequality: A macroeconomic analysis. Econometrica 68(5), 10291053.

[33] Lowe, M., C. Papageorgiou, and F. Perez-Sebastian (2018). The public and private MPK. Economica, forthcoming.

[34] Pedroni, P. (2000). Fully modified OLS for heterogeneous cointegrated panels. Advances in Econometrics 15, 93-130.

[35] Pedroni, P. (2001). Purchasing power parity tests in cointegrated panels. Review of Economics and Statistics 83(4), 727-731.

[36] Romp, W. and J. de Haan (2007). Public capital and economic growth: A critical survey. Perspektiven der Wirtschaftspolitik 8, 6-52. 
[37] Sato, K. (1967). A two-level constant-elasticity-of-substitution production function. Review of Economic Studies 34(2), 201-218.

[38] Stokey, N. L. (1996). Free trade, factor returns, and factor accumulation. Journal of Economic Growth 1(4), 421-447.

[39] Thursby, J. G. and C. K. Lovell (1978). An investigation of the Kmenta approximation to the CES function. International Economic Review 19(2), 363-377.

[40] Turnovsky, S. J. (2011). Capital Accumulation and Economic Growth in a Small Open Economy. Cambridge, U.K.: Cambridge University Press. 
Figure A1. List of Countries by Income Group

\begin{tabular}{|c|c|c|c|c|}
\hline \multirow{2}{*}{$\begin{array}{l}\text { Advanced } \\
\text { Australia }\end{array}$} & \multicolumn{2}{|l|}{ Emerging } & \multicolumn{2}{|l|}{ LIDCs } \\
\hline & Albania* & Kuwait* & Bangladesh & Sierra Leone \\
\hline Austria & Algeria & Lebanon* & Benin & Sudan* $*$ \\
\hline Belgium & Angola* & Malaysia & Bhutan* & Tajikistan** \\
\hline Canada & Antigua and Barbuda* & Maldives* & Bolivia & Tanzania \\
\hline Czech** & Argentina & Mauritius & Burkina Faso & Togo \\
\hline Estonia** & Armenia** & Mexico & Burundi & Uganda \\
\hline Finland & Azerbaijan** & Montenegro** & Cambodia* & Uzbekistan** \\
\hline France & Bahrain* & Morocco & Cameroon & Vietnam* \\
\hline Germany & Barbados & Namibia & Central Africa & Yemen* \\
\hline Greece & Belize* & Oman* & Chad & Zambia \\
\hline HK SAR & Bosnia and H.** & Pakistan & Comoros & Zimbabwe \\
\hline Iceland & Botswana & Panama & Congo, D. & \\
\hline Israel & Brazil & Paraguay & Congo, R. & \\
\hline Italy & Bulgaria* & Peru & Cote d'Ivoire & \\
\hline Japan & Cabo Verde & Philippines & Ethiopia & \\
\hline Korea & Chile & Poland* & Gambia & \\
\hline Latvia** $^{*}$ & China & Romania & Ghana & \\
\hline Lithuania** & Colombia & Russia** & Guinea & \\
\hline Luxembourg & Costa Rica & Saudi Arabia* & Guinea-Bissau & \\
\hline Macao SAR* & Croatia** & Serbia** & Haiti & \\
\hline Netherlands & Dominica* & Seychelles & Honduras & \\
\hline New Zealand & Dominican Republic & South Africa & Kenya & \\
\hline Portugal & Ecuador & Sri Lanka & Lesotho & \\
\hline Singapore & Egypt & St. Kitts and Nevis* & Madagascar & \\
\hline Slovakia** & El Salvador & St. Lucia* & Malawi & \\
\hline Switzerland & Equatorial Guinea* & St. Vincent* & Mali & \\
\hline Taiwan POC & Fiji & Suriname* & Moldova** & \\
\hline UK & Gabon & Swaziland* & Mongolia* & \\
\hline United States & Georgia** & Syria & Mozambique & \\
\hline & Grenada* & Thailand & Myanmar & \\
\hline & Guatemala & Trinidad and Tobago & Nepal & \\
\hline & India & Tunisia & Nicaragua & \\
\hline & Indonesia & Turkey & Niger & \\
\hline & Iran & Ukraine** & Nigeria & \\
\hline & Iraq* & UAE* & Rwanda & \\
\hline & Jordan & Uruguay & Sao Tome and P.* & \\
\hline & Kazakhstan** & Venezuela & Senegal & \\
\hline
\end{tabular}

Sources: Penn World Table version 9.0, IMF World Economic Outlook Oct 2016, and authors' estimates.

Note: Data start from 1960 if no special notation; * and ** indicates that data start from 1970 and 1990, respectively.

Data for the Republic of the Sudan exclude South Sudan after 2011. 